\title{
Correction to: Role of non-coding RNA networks in leukemia progression, metastasis and drug resistance
}

\author{
Ajaz A. Bhat ${ }^{1}$, Salma N. Younes ${ }^{2,3}$, Syed Shadab Raza ${ }^{4}$, Lubna Zarif ${ }^{2,3}$, Sabah Nisar', Ikhlak Ahmed ${ }^{1}$, Rashid Mir ${ }^{5}$, \\ Sachin Kumar ${ }^{6}$, Surender K. Sharawat ${ }^{6}$, Sheema Hashem ${ }^{1}$, Imadeldin Elfaki ${ }^{7}$, Michal Kulinski ${ }^{3}$, Shilpa Kuttikrishnan ${ }^{3}$, \\ Kirti S. Prabhu' ${ }^{3}$, Abdul Q. Khan ${ }^{3}$, Santosh K. Yadav' ${ }^{1}$, Wael El-Rifai ${ }^{8}$, Mohammad A. Zargar ${ }^{9}$, Hatem Zayed ${ }^{2}$, \\ Mohammad Haris ${ }^{1,10^{*}}$ and Shahab Uddin ${ }^{3^{*}}$
}

\section{Correction to: Mol Cancer 19, 57 (2020) https://doi.org/10.1186/s12943-020-01175-9}

Following the publication of the original article [1], authors have noticed that one of the authors, Syed Shadab Raza, was missing in the Authors' Contributions section. Please see below updated section.

\section{Authors' contributions}

Conceptualization, AAB, SYN, MH and SU; writingoriginal draft preparation, $\mathrm{AAB}, \mathrm{SN}, \mathrm{IA}, \mathrm{RM}, \mathrm{SKS}, \mathrm{LZ}$, IE, SK, KSP, AQ, SK and SU; writing-review and editing, $\mathrm{AAB}, \mathrm{SN}, \mathrm{MH}, \mathrm{MK}, \mathrm{WER}, \mathrm{HZ}, \mathrm{MAZ}$ and SU; Revision of manuscript, AAB, SSR, SN, IA, RM, SKS, LZ, IE, SK, KSP, AQ, SK, SKY and SU; supervision, AAB, SU, $\mathrm{MH}, \mathrm{SN}, \mathrm{MK}$, WER and SU. AAB, SSR and LZ - Preparation of Illustrations. All authors have read and approved the final version of the manuscript.

\footnotetext{
Author details

${ }^{1}$ Functional and Molecular Imaging Laboratory, Cancer Research Department, Sidra Medicine, P.O. Box 26999, Doha, Qatar. ${ }^{2}$ Department of Biomedical Science, College of Health Sciences, Qatar University, Doha, Qatar. ${ }^{3}$ Translational Research Institute, Academic Health System, Hamad Medical Corporation, P.O. Box 3050, Doha, Qatar. " Laboratoryfor Stem Cell \& Restorative Neurology, Era's Lucknow Medical College and Hospital,
}

The original article can be found online at https://doi.org/10.1186/s12943020-01175-9.

\footnotetext{
*Correspondence: mharis@sidra.org; harissgpgi@gmail.com;

Skhan34@hamad.qa

${ }^{1}$ Functional and Molecular Imaging Laboratory, Cancer Research Department, Sidra Medicine, P.O. Box 26999, Doha, Qatar

${ }^{3}$ Translational Research Institute, Academic Health System, Hamad Medical

Corporation, P.O. Box 3050, Doha, Qatar
}

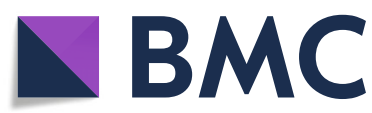

(c) The Author(s). 2020 Open Access This article is licensed under a Creative Commons Attribution 4.0 International License, which permits use, sharing, adaptation, distribution and reproduction in any medium or format, as long as you give appropriate credit to the original author(s) and the source, provide a link to the Creative Commons licence, and indicate if changes were made. The images or other third party material in this article are included in the article's Creative Commons licence, unless indicated otherwise in a credit line to the material. If material is not included in the article's Creative Commons licence and your intended use is not permitted by statutory regulation or exceeds the permitted use, you will need to obtain permission directly from the copyright holder. To view a copy of this licence, visit http://creativecommons.org/licenses/by/4.0/ The Creative Commons Public Domain Dedication waiver (http://creativecommons.org/publicdomain/zero/1.0/) applies to the data made available in this article, unless otherwise stated in a credit line to the data.

Lucknow, Uttar Pradesh, India. ${ }^{5}$ Department of Medical Lab Technology, Faculty of Applied Medical Sciences, University of Tabuk, Tabuk, Saudi Arabia. ${ }^{6}$ Department of Medical Oncology, Dr. B. R. Ambedkar Institute Rotary Cancer Hospital, All India Institute of Medical Sciences, New Delhi, India. ${ }^{7}$ Department of Biochemistry, Faculty of Science, University of Tabuk, Tabuk, Saudi Arabia. ${ }^{8}$ Department of Surgery, Sylvester Comprehensive Cancer Center, Miller School of Medicine, University of Miami, Miami, Florida, USA. ${ }^{9}$ Department of Biotechnology, Central University of Kashmir, Ganderbal, Jammu and Kashmir, India. ${ }^{10}$ Laboratory Animal Research Center, Qatar University, Doha, Qatar.

Published online: 29 December 2020

Reference

1. Bhat AA, Younes SN, Raza SS, et al. Role of non-coding RNA networks in leukemia progression, metastasis and drug resistance. Mol Cancer. 2020;19: 57 https://doi.org/10.1186/s12943-020-01175-9. 